\title{
The Polish Pension Reform of 2011
}

\author{
MARIUSZ DYBAE*
}

\section{INTRODUCTION}

In 2011, the government introduced significant changes ${ }^{1}$ to the Polish pension system, which had previously been reformed in $1999^{2}$. In 1999 , a mixed system referred to as the multipillar system (three pillars) was established $^{3}$ in order to reduce various risks ${ }^{4}$. The first pillar was publicly managed, mandatory, funded by contributions, based on a notional defined contribution (NDC), financed using the pay-as-you-go method (PAYG). The second pillar was also mandatory, and consisted of Open Pension Funds (Otwarte Fundusze Emerytalne - OFE) managed by Private Pension Entities (Powszechne Towarzystwa Emerytalne - PTE), based on a defined contribution but financed using the funded method. The third pillar was composed of various forms of private, voluntary savings schemes based on a defined contribution and financed using the funded method ${ }^{5}$.

Studies of pension funds are extremely important. Why? Firstly, because of the mandatory character of participation, pension funds affect the whole of society. According to the Polish Financial Supervision Authority (Komisja Nadzoru Finansowego - KNF), at the end of 2012 there were 16 million people ( $42 \%$ of the population) who had accounts in an OFE $^{6}$. Secondly, because of the amount of the money involved. According to the Polish Financial Supervision Authority, at the end of year 2012 the net assets of pension funds amounted to PLN 269.6 billion ${ }^{7}$. Thirdly, because of their

DOI: $10.1515 /$ wrlae-2015-0003

*PhD, LLM; Assistant Professor; University of Wroclaw, Institute of Economic Sciences; mariusz_dybal@prawo.uni.wroc.pl.

${ }^{1}<$ http://isap.sejm.gov.pl/DetailsServlet?id=WDU20110750398 $>$ accessed 8 October 2013.

${ }^{2}<$ http://www.knf.gov.pl/en/Images/ustawa\%20OFE_eng_ver\%20ostat_21.07_tcm81-

5092.pdf $>$ accessed 8 October 2013.

3 Mariusz Dybał, 'Reformy systemów emerytalnych' (2013) 11 (2) Part 5 Zarzadzanie $i$ Finanse. Journal of Management and Finance 289-303.

${ }^{4}$ Mariusz Dybał, 'The importance of pension funds among the other institutions of Polish financial system' [2013a] Proceedings from 5th Annual International Scientific Conference 'Region in the Development of Society 2013' 183.

${ }^{5}$ Mariusz Dybał, 'Funded pension - a remedy for an ageing society?' (2012) 2 (2) Wroclaw Review of Law, Administration and Economics 109-126.

${ }^{6}$ Urząd Komisji Nadzoru Finansowego, 'Rynek otwartych funduszy emerytalnych w IV kwartale 2012 roku' (2013) 12.

7 ibid. 
impact, reach, portfolio policies, rights and obligations, pension funds are regulated by the government. Fourthly, because the issue of sustainability of the pension system is a matter of public finances. This in turn leads to the relationship between the government and pension funds taking on real significance.

Because of the importance of this research area, pension funds are widely discussed in subject literature around the world. Pension funds have been the subject of works by Stiglitz ${ }^{8}$, Barr ${ }^{9}$, papers under the aegis of the International Labour Organisation ${ }^{10}$, the World Bank ${ }^{11}, \mathrm{OECD}^{12}$, the $\mathrm{EU}^{13}$ and FIAP $^{14}$. As the subject is an interdisciplinary one, authors have considered pension systems within the framework of diverse research approaches: pension economics as a theory of economics, social policy, finance, insurance and management. As for Polish contributions to the science of pension funds, we may recall the work of Golinowska ${ }^{15}$, Szumlicz ${ }^{16}$, Żukowski ${ }^{17}$, Jędrasik-Jankowska ${ }^{18}$, Góra ${ }^{19}$, Chłoń-Domińczak ${ }^{20}$, Stańko $^{21}$, Dyba $^{22}$, Chybalski $^{23}$ and Jakubowski ${ }^{24}$. In the early stages, these authors dedicated their research to studying the structures and reforms of pension systems. They therefore described the legal, economic, social and organizational aspects of pension systems ${ }^{25}$. As the system matured, studies were also conducted on the activities of pension funds. Nowadays, research

\footnotetext{
${ }^{8}$ Joseph E. Stiglitz, Economics of the Public Sector (W.W. Norton \& Company 1986).

${ }^{9}$ Nicholas Barr, 'Economic Theory and the Welfare State - A Survey and Interpretation' (1992) 30 (2) Journal of Economic Literature 741-803.

10 'Social Insurance and Social Protection' (Report of the Director-General, Part 1. 80th Session of the International Labour Organisation Conference. ILO 1993).

${ }^{11}$ World Bank, 'Averting the OLD Age Crisis. Policies to Protect the Old and Promote Growth' (1994).

12 OECD, 'Maintaining Prosperity in an Ageing Society' (1998).

${ }^{13}$ EU, 'Comparative Tables on Social Protection in the Member States and the European Economic Area. Mutual Information System on Social Protection in the EU Member States and the EEA' (2002); Commission, 'Communication from the Commission to the Council, the European Parliament, the Economic and Social Committee and the Committee of the Regions: Strengthening the Social Dimension of the Lisbon strategy: Streamlining Open Coordination in the Field of Social Protection' COM (2003) 261 final.

${ }^{14}$ FIAP, 'Pension Reforms: Results and Challenges' (2003).

15 Stanisława Golinowska, Polityka społeczna państwa $w$ gospodarce rynkowej. Studium ekonomiczne (PWN 1994).

${ }^{16}$ Tadeusz Szumlicz, Modele polityki społecznej (SGH 1994).

17 Maciej Żukowski, Wielostopniowe systemy zabezpieczenia emerytalnego $w$ Unii Europejskiej $i$ w Polsce. Między Państwem a rynkiem (AE Poznań 1997).

${ }^{18}$ Inetta Jędrasik-Jankowska, Ubezpieczenia emerytalne. Trzy filary (PWN 2001).

${ }^{19}$ Marek Góra, System emerytalny (PWE 2003).

${ }^{20}$ Agnieszka Chłoń-Domińczak, Evaluation of reform experiences in Eastern Europe (FIAP 2003).

${ }^{21}$ Dariusz Stańko, 'Polish Pension Funds - Does The System Work? Cost, Efficiency and Performance Measurement Issues' [2003] The Pension Institute Discussion Paper PI-0302.

${ }^{22}$ Mariusz Dybał, Efektywność inwestycyjna funduszy emerytalnych (CeDeWu 2008).

${ }^{23}$ Filip Chybalski, Skuteczność i efektywność systemu emerytalnego. Koncepcja analizy $i$ próba pomiaru (Wydawnictwo Politechniki Łódzkiej 2012).

${ }^{24}$ Sebastian Jakubowski, Prawno-ekonomiczne aspekty gromadzenia i lokowania środków przez Otwarty Fundusz Emerytalny (Prawnicza i Ekonomiczna Biblioteka Cyfrowa 2013).

${ }^{25}$ Mariusz Dybał, 'The influence of the financial crisis on the Polish open pension funds system' [2013c] Proceedings from the 13th Ernestas Galvanauskas International Scientific Conference dedicated to the 15th anniversary of the Faculty of Social Sciences 'Rethinking Regional Competitiveness'.
} 
is focused on the impact of the financial, economic and fiscal crisis on pension funds and pension schemes. In this respect we can recall the work of Egert ${ }^{26}$, Holzmann $^{27}$, the European Commission ${ }^{28}, \mathrm{OECD}^{29}$ and Dybał ${ }^{30}$.

However, the literature rarely features work focused on the 2011 pension reform in Poland. Perhaps this is due to the relative novelty of the subject. Hence the inspiration for this work. The research subject of the paper is the interaction between pension funds and public finances in Poland in the period 1999-2010. The research aim of this study is to assess the pension reform of 2011 in the context of public finances. To achieve this goal, the author decided to implement the following research tasks:

- determining the causes of the 2011 pension reform;

- presenting the objectives of the 2011 pension reform;

The research period mainly covers the period of 1999-2011, and the author uses the following research methods in the work: analysis of scientific literature and normative documents, comparative analysis, statistical analysis. The basis of the study is literature and statistical data published by Eurostat, the World Bank, the Organization for Economic Cooperation and Development (OECD), the International Federation of Pension Fund Administrators (FIAP), KNF, GUS (Central Statistical Office of Poland), National Bank of Poland (NBP) and the Chamber of Fund and Asset Management (IZFiA).

\section{The Causes OF THE 2011 Pension ReFORM}

Every reform has its own goals. So it was with the reforms of 1999 and 2011. The objectives of the 1999 were as follows ${ }^{31}$ :

- The reform must lead to construction of a system that will be able to perform its function for many generations;

- The reformed system must ensure maximum social security for all citizens;

- Reform must enable the system to meet the obligations it incurred in the past;

\footnotetext{
${ }^{26}$ Balazs Égert, 'The Impact of Changes in Second Pension Pillars on Public Finances in Central and Eastern Europe' (2012) OECD Economics Department Working Papers No. 942 $<$ http://dx.doi.org/10.1787/5k9fltdtxbr6-en> accessed 8 October 2013.

${ }^{27}$ Robert Holzmann, 'Global Pension Systems and Their Reform: Worldwide Drivers, Trends, and Challenges' (2013) World Bank Social Protection \& Labor Discussion Paper No. 121368934 .

${ }^{28}$ Commission, 'WHITE PAPER. An Agenda for Adequate, Safe and Sustainable Pensions' COM (2012) 55 final.

${ }^{29}$ OECD, 'OECD Pensions Outlook 2012' <http://dx.doi.org/10.1787/9789264169401-en> accessed 8 October 2013.

${ }^{30}$ Mariusz Dybał, 'Wpływ OFE na deficyt budżetowy i dług publiczny?' [2013d] Proceedings from conference 'Finanse publiczne i prawo finansowe wobec wyzwań kryzysu finansowego'. 31 Biuro Pełnomocnika Rządu ds. Reformy Zabezpieczenia Społecznego 1997, 'Bezpieczeństwo dzięki różnorodności. Reforma systemu emerytalno-rentowego w Polsce' VII.
} 
- The cost of reforming the system cannot exceed the capacity of the economy, and financial transition costs must be spread out over a long period;

- Reform must consider the experiences of traditional pension systems, as well as new concepts taking into account the changing conditions affecting the functioning of the social security system.

As a result, the reform in 1999 was designed to meet the main objective, i.e. to ensure the highest possible level of benefits to future generations. Benefits that are protected against inflation and adequate when compared to previously earned wages, and thus contribute to the system in the form of contributions while maintaining the guarantee of insurance for current beneficiaries. Along with diverse sources of retirement funding (the multipillar system $)^{32}$ and permanence and clarity of the new rules, the pension system enabled effective responses to negative trends. Thus, on the one hand the government wanted to provide the highest possible income for the elderly, and on the other to ensure that the pension system was not an excessive burden on public finances. It would seem that this was an attempt to reconcile contradictory objectives: pension adequacy and financial stability of the pension system $^{33}$.

However, it appears that the result was satisfactory. As a result of the 1999 reform it is expected that in the period from 2010 to 2060, spending on the pension system in Poland will decrease from 11.8\% of GDP to $9.6 \%$ of GDP. The question of whether this is a lot or a little can be answered by analysing the data collected in Table 1, which shows projected age-related expenditures. Based on the data in Table 1, we may state that in the period 2010-2060, age-related expenditures in the European Union will increase on average by $1.6 \%$ from $11.3 \%$ of GDP to $12.9 \%$ of GDP. Pension systems in the euro zone will be more generous, as it is predicted that in the period 20102060 age-related expenditures in the euro zone will increase by an average of $2 \%$ of GDP from $12.2 \%$ to $14.2 \%$ of GDP. The sizes of the expected changes are diverse. On one side are countries in which age-related expenditures will increase significantly: Luxembourg (9.4\% of GDP), Cyprus ( $8.7 \%$ of GDP), Slovenia (7.1\% of GDP), Belgium (5.6\% of GDP) and Malta (5.5\% of GDP). On the other side there are countries in which a decrease in age-related expenditures is forecast: Latvia (-3.8\% of GDP), Poland ( $-2.2 \%$ of GDP), Estonia ( $-1.1 \%$ of GDP), Italy ( $-0.9 \%$ of GDP) and Denmark (- $0.6 \%$ of GDP). It should be noted, however, that in the vast majority of cases spending is expected to rise (22 EU Member States) rather than fall (5 EU Member States).

Table 1. Projected age-related expenditures 2010-2060 as a percentage of GDP

\begin{tabular}{|l|r|r|l|r|r|}
\hline & 2010 & 2060 & & 2010 & \multicolumn{1}{|c|}{2060} \\
\hline Belgium & 11.0 & 5.6 & Hungary & 11.9 & 2.8 \\
\hline Bulgaria & 9.9 & 1.1 & Malta & 10.4 & 5.5 \\
\hline Czech Republic & 9.1 & 2.7 & The Netherlands & 6.8 & 3.6 \\
\hline Denmark & 10.1 & -0.6 & Austria & 14.1 & 2.0 \\
\hline Germany & 10.8 & 2.6 & Poland & 11.8 & -2.2 \\
\hline
\end{tabular}

32 Mariusz Dybał, 'Istota i rodzaje systemów emerytalnych' in Leon Olszewski (ed), Ekonomia 18. Transformacje systemu gospodarczego (Wydawnictwo Uniwersytetu Wrocławskiego 2010) 229-246.

${ }^{33}$ Mariusz Dybał, 'Reformy systemów emerytalnych' (n 3$)$ 289-303. 


\begin{tabular}{|l|r|r|l|r|r|}
\hline Estonia & 8.9 & -1.1 & Portugal & 12.5 & 0.2 \\
\hline Ireland & 7.5 & 4.1 & Romania & 9.8 & 3.7 \\
\hline Greece & 13.6 & 1.0 & Slovenia & 11.2 & 7.1 \\
\hline Spain & 10.1 & 3.6 & Slovakia & 8.0 & 5.2 \\
\hline France & 14.6 & 0.5 & Finland & 12.0 & 3.2 \\
\hline Italy & 15.3 & -0.9 & Sweden & 9.6 & 0.6 \\
\hline Cyprus & 7.6 & 8.7 & United Kingdom & 7.7 & 1.5 \\
\hline Latvia & 9.7 & -3.8 & Norway & 9.3 & 4.9 \\
\hline Lithuania & 8.6 & 3.5 & European Union 27 & 11.3 & 1.5 \\
\hline Luxembourg & 9.2 & 9.4 & Euro zone & 12.2 & 2.0 \\
\hline
\end{tabular}

Source: 'The 2012 Ageing Report. Economic and budgetary projections for the 27 EU Member States (2010-2060)' (European Commission 2012) 38.

Table 1 shows that the reform in 1999 was effective. Thus, the question arises as to why the 2011 reform was implemented. The problem is the year 2060, resulting from the financing costs of the transition. Recall that as a result of the 1999 reform, the labour of active members of the workforce funds both the old system as well as their future retirement (the new system). This will take place as long as long as those who have retired under the terms of the old system are alive. According to the authors of the 1999 reform, this negative situation (Social Security expenditures greater than revenues) should take place only until $2010^{34}$. In addition, it was assumed that the transition costs (contributions transferred by Social Security Institution to OFE) would be funded from the proceeds of privatization and reforms that put an end to the privileges of particular social groups, thereby reducing state spending ${ }^{35}$.

Data on these transition costs are presented in Table 2. From Table 2 it should be noted that transition costs rose continuously during the period 1999-2010. During the period under analysis, contributions transferred from Social Security to pension funds increased from PLN 2,262.7 million to PLN 22,347.2 million. This represents an increase from 0.34\% of GDP in 1999 to $1.58 \%$ of GDP in 2010. These contributions amount to the transition costs of the reform, and in Social Security Institution accounts they are referred to as refunds for Social Security related to the loss of contributions transferred to pension funds.

Table 2. Contributions transferred by the Social Security Institution (ZUS) to OFE, 1999-2010

\begin{tabular}{|c|c|c|}
\hline & PLN million & As percentage of GDP $(\%)$ \\
\hline 1999 & $2,262.7$ & 0.34 \\
\hline 2000 & $7,548.2$ & 1.01 \\
\hline 2001 & $8,652.9$ & 1.11 \\
\hline 2002 & $9,490.4$ & 1.17 \\
\hline 2003 & $9,868.0$ & 1.17 \\
\hline 2004 & $10,613.0$ & 1.15 \\
\hline 2005 & $12,575.4$ & 1.28 \\
\hline 2006 & $14,920.4$ & 1.41 \\
\hline 2007 & $16,219.3$ & 1.38 \\
\hline 2008 & $19,911.5$ & 1.56 \\
\hline 2009 & $21,086.0$ & 1.57 \\
\hline
\end{tabular}

\footnotetext{
${ }^{34}$ Agnieszka Chłoń, Marek Góra and Michał Rutkowski, Shaping Pension Reform in Poland: Security Through Diversity (The World Bank 1999) 49.

35 ibid $42-51$.
} 


\begin{tabular}{|l|r|r|}
\hline 2010 & $22,347.2$ & 1.58 \\
\hline
\end{tabular}

Source: own calculation based on 'Rocznik Statystyczny Ubezpieczeń Społecznych. System pozarolniczy 1999-2002' (ZUS 2004) 13; 'Ważniejsze informacje z zakresu ubezpieczeń społecznych 2005 r.' (ZUS 2006) 7-9; 'Ważniejsze informacje z zakresu ubezpieczeń społecznych 2006 r.' (ZUS 2007) 8-10; 'Ważniejsze informacje z zakresu ubezpieczeń społecznych 2007 r.' (ZUS 2008) 8-10; 'Ważniejsze informacje z zakresu ubezpieczeń społecznych 2008 r.' (ZUS 2009) 8-10; 'Ważniejsze informacje z zakresu ubezpieczeń społecznych 2009 r.' (ZUS 2010) 8-10; 'Ważniejsze informacje z zakresu ubezpieczeń społecznych $2010 \quad$ r.' (ZUS 2011) 8-10; $<$ http://www.stat.gov.pl/gus/wskazniki_makroekon_PLK_HTML.htm> accessed 8 October 2013.

As already mentioned, it was assumed that the transition costs would be financed by privatization. Data on revenues from privatization, net proceeds from privatization and transition costs are presented in Table 3 . If in the period 1999-2010 all privatization revenues (PLN 102,216 million) had been transferred to the refund in respect of contributions to pension funds (PLN 155,495.0 million), only 66\% of the refund would have been financed. This was caused by poorer-than-expected revenues from privatization and an expansion of the list of purposes for which the proceeds of privatization were allocated. ${ }^{36}$ As a result, after subtracting statutory deductions, the net proceeds from privatization in the period 1999-2010 amounted to PLN $74,117.8$ million. This enabled financing of only $48 \%$ of the refund of contributions to pension funds.

Table 3. Privatization revenues (PLN million)

\begin{tabular}{|l|r|r|r|}
\hline & $\begin{array}{c}\text { Revenues from } \\
\text { privatization }\end{array}$ & $\begin{array}{c}\text { Net proceeds from } \\
\text { privatization }\end{array}$ & Contributions from ZUS to OFE \\
\hline 1999 & 13,383 & $13,347.5$ & $2,262.7$ \\
\hline 2000 & 27,323 & $26,746.2$ & $7,548.2$ \\
\hline 2001 & 6,835 & $6,490.1$ & $8,652.9$ \\
\hline 2002 & 2,862 & $1,971.6$ & $9,490.4$ \\
\hline 2003 & 4,143 & $2,962.9$ & $9,868.0$ \\
\hline 2004 & 10,254 & $7,370.5$ & $10,613.0$ \\
\hline 2005 & 3,848 & $2,772.3$ & $12,575.4$ \\
\hline 2006 & 621 & 446.2 & $14,920.4$ \\
\hline 2007 & 1,947 & $1,394.1$ & $16,219.3$ \\
\hline 2008 & 2,371 & $1,021.3$ & $19,911.5$ \\
\hline 2009 & 6,592 & 568.9 & $21,086.0$ \\
\hline 2010 & 22,037 & $9,026.2$ & $22,347.2$ \\
\hline Total & $\mathbf{1 0 2 , 2 1 6}$ & $\mathbf{7 4 , 1 1 7 . 8}$ & $\mathbf{1 5 5 , 4 9 5 . 0}$ \\
\hline
\end{tabular}

Source: own calculation based on

$<\mathrm{http} / / /$ www.senat.gov.pl/gfx/senat/userfiles/_public/k8/dokumenty/stenogram/oswiadczenia/wyrowi nski/3201o.pdf> accessed 8 October 2013;

$<$ http://prywatyzacja.msp.gov.pl/portal/pr/349/24611/?poz=1> accessed 8 October 2013;

$<\mathrm{http} / / /$ prywatyzacja.msp.gov.pl/portal/pr/60/1529/Zestawienie_przychodow_z_prywatyzacji_stan_ na_31122005_r.html $>$ accessed 8 October 2013.

Since privatization revenues proved insufficient, let us examine if revenues from social security contributions are sufficient to fund social security spending. Data on revenues, expenditures and revenues/expenditures ratios is presented in Table 4 .

\footnotetext{
${ }^{36}$ Mariusz Dybał, 'Finansowanie okresu przejściowego' [2013e] Proceedings from the 3rd
} 'Ogólnopolska Konferencja Emerytalna' held on 5-6 November 2013. 
Table 4. Social Security Institution - expenditures and revenues from contributions, 1999-2010

\begin{tabular}{|l|r|r|r|}
\hline & $\begin{array}{c}\text { Expenditures (PLN } \\
\text { billion) }\end{array}$ & Revenues (PLN billion) & Revenues/expenditures ratio (\%) \\
\hline 1999 & 77.1 & 64.1 & 83.1 \\
\hline 2000 & 82.4 & 65.6 & 79.6 \\
\hline 2001 & 92.5 & 69.9 & 75.1 \\
\hline 2002 & 95.4 & 68.2 & 71.5 \\
\hline 2003 & 98.6 & 70.3 & 71.3 \\
\hline 2004 & 104.1 & 74.0 & 71.2 \\
\hline 2005 & 107.5 & 78.2 & 72.8 \\
\hline 2006 & 115.7 & 81.3 & 70.3 \\
\hline 2007 & 121.1 & 89.4 & 73.8 \\
\hline 2008 & 135.4 & 82.7 & 61.1 \\
\hline 2009 & 151.2 & 86.5 & 57.2 \\
\hline 2010 & 160.6 & 89.4 & 55.7 \\
\hline
\end{tabular}

Source: own calculation based on 'Rocznik Statystyczny Ubezpieczeń Społecznych. System pozarolniczy 1999-2002' (ZUS 2004) 13; 'Ważniejsze informacje z zakresu ubezpieczeń społecznych 2005 r.' (ZUS 2006) 14; 'Ważniejsze informacje z zakresu ubezpieczeń społecznych 2006 r.' (ZUS 2007) 13; 'Ważniejsze informacje z zakresu ubezpieczeń społecznych 2007 r.' (ZUS 2008) 11; 'Ważniejsze informacje z zakresu ubezpieczeń społecznych 2008 r.' (ZUS 2009) 11; 'Ważniejsze informacje z zakresu ubezpieczeń społecznych 2009 r.' (ZUS 2010) 11; 'Ważniejsze informacje z zakresu ubezpieczeń społecznych 2010 r.' (ZUS 2011) 11.

Table 4 shows that in the period 1999-2010 spending continued to grow, increasing from PLN 77.1 billion in 1999 to PLN 160.6 billion in 2010. In the years under examination, revenues from contributions also increased from PLN 64.1 billion in 1999 to PLN 89.4 billion in 2010. However, the relationship between revenues and expenditures is unfavourable. In the years $1999-2010$ the revenues/expenditures ratio demonstrated a downward trend from $83.1 \%$ to $55.7 \%$. It seems that this adverse ratio is due to the situation on the labour market and, above all, numerous modifications and adjustments to the pension system. ${ }^{37}$ These changes are not always taken advantage of in order to improve the financial balance of the social security system. As a result, the assumptions underlying the reforms in 1999 failed to materialize: the abolition of sectorial and industry privileges and a surplus of revenues over expenditures for the Social Security Institution by 2010.

Thus, the loss of contributions to social security due to the introduction of pension funds cannot be financed from the proceeds of privatization. One may ask the question of whether the loss of contributions to pension funds can be financed through a state budget surplus. Table 5 presents data on the deficit / surplus both in PLN billions and PLN millions and as a percentage of GDP, as well as the impact of the funds on the state budget. Unfortunately, in the years 1999-2010 there was no budget surplus. Rather, during the entire period under examination there was a budget deficit. The lowest deficit in nominal terms was recorded in 1999 (PLN 15,386 million) and the highest in 2010 (PLN 111,291 million). On the other hand, as a percentage of GDP the lowest deficit was recorded in 2007 (1.9\%) and the highest in $2010(7.9 \%)$. Hence the conclusion that the loss in social security contributions owing to the introduction of pension funds could have increased the size of the budget deficit. When therefore taking into account

37 ibid. 
the cost of servicing debt resulting from the introduction of pension funds, the impact of these pension funds may have expanded the budget deficit from $0.4 \%$ of GDP in 1999 to $2.4 \%$ of GDP in 2010 .

Table 5. OFE influence on the Polish budget, 1999-2010

\begin{tabular}{|r|r|r|r|r|r|r|r|r|}
\hline & $\begin{array}{c}\text { Contributions } \\
\text { transferred by ZUS } \\
\text { to OFE }\end{array}$ & $\begin{array}{c}\text { Additional debt } \\
\text { service costs for } \\
\text { OFE }\end{array}$ & \multicolumn{2}{|c|}{$\begin{array}{l}\text { Impact of the OFE on } \\
\text { the budget of Poland }\end{array}$} & \multicolumn{2}{|c|}{$\begin{array}{c}\text { Budget deficit of } \\
\text { Poland }\end{array}$} \\
\cline { 2 - 10 } & $\begin{array}{c}\text { PLN } \\
\text { million }\end{array}$ & GDP \% & PLN billion & GDP \% & $\begin{array}{c}\text { PLN } \\
\text { billion }\end{array}$ & GDP \% & $\begin{array}{c}\text { PLN } \\
\text { million }\end{array}$ & GDP \% \\
\hline 1999 & $2,262.7$ & 0.34 & 0.2 & 0.0 & 2.4 & 0.4 & 15,386 & 2.3 \\
\hline 2000 & $7,548.2$ & 1.01 & 0.8 & 0.1 & 8.4 & 1.1 & 22,541 & 3.0 \\
\hline 2001 & $8,652.9$ & 1.11 & 1.8 & 0.2 & 10.5 & 1.3 & 41,095 & 5.3 \\
\hline 2002 & $9,490.4$ & 1.17 & 3.0 & 0.4 & 12.5 & 1.5 & 40,317 & 5.0 \\
\hline 2003 & $9,868.0$ & 1.17 & 3.8 & 0.5 & 13.7 & 1.6 & 52,212 & 6.2 \\
\hline 2004 & $10,613.0$ & 1.15 & 4.3 & 0.5 & 14.9 & 1.6 & 49,773 & 5.4 \\
\hline 2005 & $12,575.4$ & 1.28 & 5.1 & 0.5 & 17.7 & 1.8 & 40,057 & 4.1 \\
\hline 2006 & $14,920.4$ & 1.41 & 6.4 & 0.6 & 21.3 & 2.0 & 38,476 & 3.6 \\
\hline 2007 & $16,219.3$ & 1.38 & 7.0 & 0.6 & 23.2 & 2.0 & 22,112 & 1.9 \\
\hline 2008 & $19,911.5$ & 1.56 & 7.7 & 0.6 & 27.6 & 2.2 & 46,950 & 3.7 \\
\hline 2009 & $21,086.0$ & 1.57 & 10.0 & 0.7 & 31.1 & 2.3 & 99,596 & 7.4 \\
\hline 2010 & $22,347.2$ & 1.58 & 11.4 & 0.8 & 33.8 & 2.4 & 111,291 & 7.9 \\
\hline
\end{tabular}

Source: 'Rocznik Statystyczny Ubezpieczeń Społecznych. System pozarolniczy 1999-2002' (ZUS 2004) 13; 'Ważniejsze informacje z zakresu ubezpieczeń społecznych 2005 r.' (ZUS 2006) 7-9; 'Ważniejsze informacje z zakresu ubezpieczeń społecznych 2006 r.' (ZUS 2007) 8-10; 'Ważniejsze informacje z zakresu ubezpieczeń społecznych 2007 r.' (ZUS 2008) 8-10; 'Ważniejsze informacje z zakresu ubezpieczeń społecznych 2008 r.' (ZUS 2009) 8-10; 'Ważniejsze informacje z zakresu ubezpieczeń społecznych 2009 r.' (ZUS 2010) 8-10; 'Ważniejsze informacje z zakresu ubezpieczeń społecznych 2010 r.' (ZUS 2011) 8-10;

$<$ http://www.stat.gov.pl/gus/wskazniki_makroekon_PLK_HTML.htm> accessed 8 October 2013; $<\mathrm{http}$ ://slimak.onet.pl/_m/nb/biznes/redakcja/20131010/uzasadnieniedoprojektuustawy.pdf $>$ accessed 8 October 2013.

The annual budget deficit forced the government to roll over debt, thus enlarging it. Table 6 shows the debt of the public finance sector, broken down by state public debt (PDP) in both absolute terms and as a percentage of GDP for the years 1999-2010, as well as the impact of OFEs on the public debt of Poland. Polish public debt in nominal terms grew continuously in the years 1999-2010. While in 1999 it amounted to PLN 273.4 billion, in 2010 it amounted to PLN 747.9 billion. Taking into account the relevant GDP data, this means that in the years 1999-2010, public debt rose from $41.1 \%$ of GDP to $52.8 \%$ of GDP.

Table 6. OFEs' influence on the public debt of Poland, 1999-2010

\begin{tabular}{|r|r|r|r|r|}
\hline \multirow{2}{*}{} & $\begin{array}{c}\text { Impact of OFEs on the public debt of } \\
\text { Poland }\end{array}$ & \multicolumn{2}{c|}{ Public debt of Poland } \\
\cline { 2 - 5 } & PLN billion & GDP \% & PLN billion & GDP \% \\
\hline 1999 & 2.6 & 0.4 & 273.4 & 41.1 \\
\hline 2000 & 12.0 & 1.6 & 280.5 & 37.7 \\
\hline 2001 & 24.1 & 3.1 & 302.1 & 38.8 \\
\hline 2002 & 37.7 & 4.7 & 352.4 & 43.6 \\
\hline 2003 & 52.0 & 6.2 & 408.3 & 48.4 \\
\hline 2004 & 68.3 & 7.4 & 431.4 & 46.7 \\
\hline 2005 & 87.1 & 8.9 & 466.6 & 47.5 \\
\hline 2006 & 109.2 & 10.3 & 506.3 & 47.8 \\
\hline 2007 & 134.0 & 11.4 & 527.4 & 44.8 \\
\hline 2008 & 163.7 & 12.8 & 597.8 & 46.9 \\
\hline
\end{tabular}




\begin{tabular}{|l|r|r|r|r|}
\hline 2009 & 196.5 & 14.6 & 669.9 & 49.8 \\
\hline 2010 & 232.9 & 16.4 & 747.9 & 52.8 \\
\hline
\end{tabular}

Source: Own calculations based on 'Zadłużenie sektora finansów publicznych IIkw/2013. Biuletyn kwartalny' (Ministerstwo Finansów 2013); 'Zadłużenie sektora finansów publicznych IVkw/2001. Biuletyn kwartalny' (Ministerstwo Finansów 2002 ); <http://slimak.onet.pl/_m/nb/biznes/redakcja/20131010/uzasadnieniedoprojektuustawy.pdf > accessed 8 October 2013 .

According to the Polish government ${ }^{38}$, the public debt would be lower without pension funds. In 1999, public debt without accounting for pension funds amount to only $40.7 \%$ instead of $41.1 \%$, while in 2010 public debt without accounting for pension funds would be at a level of $36.4 \%$ rather than $52.8 \%$. This means that over the years 1999-2010 public debt without pension funds would have been gone from less than $0.4 \%$ in 1999 to approximately $16.4 \%$ in 2010 . Thus, public debt in the period 1999-2010 would have declined by $5.5 \%$. So if there had been no OFE, the first prudential threshold of public debt $(50 \%)^{39}$ would not have been exceeded in 2010, and Article 216 of the Polish Constitution, which prohibits the public debt exceeding three-fifths of gross domestic product, would not have been in danger of being violated $^{40}$. And so we come to the heart of the matter. The cause of the pension reform in 2011 was to overcome the unfavourable evolution of the public debt. This is confirmed by the words of the legislature. In document No. 3946 of 10 March 2011, which contains the justification for the Bill to amend certain laws relating to the operation of the social security system, we may read the following:

After a decade of the system's operation it should be noted, however, that the reform requires reasonable adjustments. These adjustments should primarily focus on issues related to the growing public debt, which is caused by the need to cover the shortfall in the Social Security Fund (FUS) as a result of the transfer of pension contributions to pension funds. This increases the borrowing requirement and debt accumulation. Lowering borrowing needs is important to maintain the stability and reliability of the fiscal situation ${ }^{41}$.

However, it should be noted that pension funds cannot be regarded as the sole source of problems in public finances. Other sources of the general deficit include inaction and decisions whose effects on public finances were worse than originally expected. So why the pension reform of 2011? Simply put, it is easier for politicians to make changes in private pension funds, which receive bad press, than to make difficult welfare sector reforms limiting privileges.

\footnotetext{
${ }^{38}$ Print No 3946 of 10 March $201159<\mathrm{http} / / / \mathrm{ww} 2$. senat.pl/k7/dok/sejm/073/3946.pdf $>$ accessed 8 October 2013.

${ }^{39}$ Art. 86 of the Public Finance Act (2009).

${ }^{40}<\mathrm{http}$ ://www.sejm.gov.pl/prawo/konst/angielski/kon1.htm> accessed 8 October 2013.

${ }^{41}$ Print No 3946 of 10 March $201159<$ http://ww2.senat.pl/k7/dok/sejm/073/3946.pdf $>$ accessed 8 October 2013.
} 


\section{THE OBJECTIVES OF 2011 PENSION REFORM}

In the assumptions of the Bill amending the law on funded pensions and some other laws (Draft of 20 July 2010) we may read:

The project involves an adjustment of the pension system reformed in 1999 which will enable the achievement of the long-term goals of the pension reform. The proposed revision is necessary to protect the interests of the insured and the continued existence of the pension system without undermining the foundation of state action: the soundness and sustainability of budget policy and fiscal policy. The draft proposes adjusting the level of funding for the second pillar of the pension system to the actual financial capabilities of Poland, as well as the simultaneous implementation of regulations to enable payment of benefits from the funds accumulated in the second pillar and to improve the efficiency of its operations. Adjusting the level of funding of the second pillar of the pension system to the actual financial capabilities of Poland will, in the short term, lead to the rehabilitation of public finances while in the long-term it will have a positive impact by way of substantial improvement in the condition of the public finance sector; this includes both the Social Security Fund (FUS) and the state budget ${ }^{42}$.

The changes were introduced in the Act of 25 March 2011 on the amendment of certain laws relating to the operation of the social security system (Journal of Laws 2011, no 75, item 398 with amendments) ${ }^{43}$. These changes can be categorized in the following groups:

- Reduction of contributions transferred to pension funds;

- OFE investment limits;

- Distribution of funds collected in the subaccount in Social Security Institution under the second pillar in the event of dissolution of a marriage, dissolution of a joint marital estate and death;

- Promoting supplemental insurance;

- Acquisition activity - direct sales.

The most important changes are those occurring within the first group. The integrity of the second pillar will be maintained, which will continue to reach the target of a $7.3 \%$ pension contribution. According to the new law, contributions transferred to pension funds will, however, be reduced. In effect, $2.3 \%$ of pension contributions will be transferred in cash to pension funds (in 2011), and the remainder will be recorded in individual subaccounts in the Social Security Institution. In subsequent years, pension contributions transferred to pension funds will be set in accordance with the values provided in Table 7 .

\footnotetext{
42 'Założenia do projektu ustawy zmieniającej ustawę o emeryturach kapitałowych oraz niektóre inne ustawy.

$\begin{array}{lllllll}\text { Projekt } & \mathrm{z} & \text { dnia } & 20 & \text { lipca } & 2010 & \text { r.' }\end{array}$ $<$ http://www.mpips.gov.pl/download/gfx/mpips/pl/defaultopisy/5204/1/1/22-07-ek-ost-w-izestawienie-uwag-23-07-10.pdf $>$ accessed 8 October 2013.

${ }^{43}<\mathrm{http}$ ://www.infor.pl/dziennik-ustaw,rok,2011,nr,75/poz,398, ustawa-z-dnia-25-marca2011-r-o-zmianie-niektorych-ustaw-zwiazanych-z.html\#> accessed 8 October 2013.
} 
Table 7. Schedule of contributions transferred to the second pillar

\begin{tabular}{|l|r|r|}
\hline & $\begin{array}{c}\text { Portion of the contribution } \\
\text { transferred to the subaccount } \\
\text { in ZUS (in \% of the base } \\
\text { premium) }\end{array}$ & $\begin{array}{c}\text { Portion of the contribution } \\
\text { transferred to pension funds } \\
\text { in cash (in \% of the base } \\
\text { premium) }\end{array}$ \\
\hline 2011 & 5.0 & 2.3 \\
\hline 2012 & 5.0 & 2.3 \\
\hline 2013 & 4.5 & 2.8 \\
\hline 2014 & 4.2 & 3.1 \\
\hline 2015 & 4.0 & 3.3 \\
\hline 2016 & 4.0 & 3.3 \\
\hline 2017 and beyond & 3.8 & 3.5 \\
\hline Source: own calculation. &
\end{tabular}

Ultimately, $3.5 \%$ of the pension contribution will be transferred to pension funds. The choice of this direction for change is dictated by concern for the situation of the public finance sector. In the period of increased uncertainty from 2011 to 2012 there was a significant reduction in the level of contributions to pension funds, to $2.3 \%$ of the base premium. In the following years, assuming an improvement in public finances, the portion of the contribution transferred to pension funds will be raised to $3.5 \%$ of the base premium. Funds held in the sub-account in ZUS will be indexed according to average nominal GDP growth over the preceding five years.

The new law has raised the limit on investment in equities. According to the new law, OFE investments in various categories may not exceed $90 \%$ of assets in respect of investments in shares of companies listed on a regulated stock market, pre-emptive rights, rights to shares and bonds convertible into shares of these companies, and national investment fund shares. The target limit is to be reached in 2034. In accordance with the regulation, the limit was raised from $40 \%$ to $45 \%$ in 2012; in 2013 and 2014, the limit will rise to $47.5 \%$ and $50 \%$ respectively, after which it will increase annually by 2 percentage points until reaching the target $(90 \%)$.

Contributions to the sub-account in the Social Security Institution will be divided in the event of divorce or annulment of marriage, termination of communal property during a marriage or contractual exclusion or limitation of statutory commonality between the insured and his/her spouse, and in the case of death of the insured. Assets attributable to the heirs of a deceased's estate will be paid in cash and recorded in their sub-accounts under the same principles as currently apply to OFEs.

In respect of promoting supplemental insurance, the new law provides for the establishment of individual pension protection system accounts (IKZE) and assumes that IKZE deposits will be tax-deductible. The value of contributions to IKZE was set at $4 \%$ of the base pension contributions.

At the same time, in order to reduce the cost of pension fund operations, 1 January 2012 marked the entry into force of provisions prohibiting active pursuit of clients for pension funds, as well as the introduction of self-selection performed on the basis of the insured receiving unified, objective and timely information about open pension funds prepared and published by the Financial Supervision Commission (KNF).

All of these changes have yet to achieve the following objective of the pension reform of 2011: 
The main objective of the proposed changes is to reduce the rate of growth of the public debt by reducing the cost of introducing the second pillar, while maintaining the neutrality of the mandatory portion of the pension system to pensions as a whole, and to stimulate the growth of retirement savings and thus overall replacement rates ${ }^{44}$.

\section{CONCLUSIONS}

The purpose of the article was to analyse the pension reform of 2011. Although the period from the creation of pension funds (1999) to 2010 was studied, some of the data involved the following decade and 2060. On the basis of the presented study it should be noted that more research is needed, particularly on the effects of the introduced reforms. Nevertheless, the objective of the study was achieved. The following conclusions can be drawn:

- In the years 1999-2010 the revenues/expenditures ratio of the Social Security Institution recorded a downward trend, decreasing from $83.1 \%$ to $55.7 \%$. It seems that this adverse ratio is due to the situation on the labour market and, above all, numerous modifications and adjustments to the pension system;

- In the period 1999-2010, net proceeds from privatization amounting to PLN 74,117.8 million were achieved, which financed only $48 \%$ of refunds of contributions to pension funds. The remainder was financed from the state budget;

- Unfortunately, in the years 1999-2010 there was no budget surplus. Hence the conclusion that the loss in social security contributions in respect of the introduction of pension funds has increased the portion of the budget deficit being financed. Thus, taking into account the cost of debt service resulting from the introduction of pension funds, the impact of pension funds was to expand the budget deficit from $0.4 \%$ of GDP in 1999 to $2.4 \%$ of GDP in 2010;

- The annual budget deficit forced the government to roll over debt, thus enlarging it. This means that in the years 1999-2010 the public debt rose from $41.1 \%$ of GDP to $52.8 \%$ of GDP. According to the government, in the period 1999-2010 the public debt without pension funds would be reduced by approximately $0.4 \%$ in 1999 to roughly $16.4 \%$ in 2010 . So if had been no OFE, the first public debt safety threshold (50\%) would not have been exceeded in 2010, and there would have been no danger of violating Article 216 of the Polish Constitution, which prohibits the public debt from exceeding threefifths of gross domestic product;

- The ultimate justification of the 2011 pension reform was to counteract the unfavourable evolution of the public debt;

- The reform of the pension system in 2011 reduced the contribution transferred to pension funds from $7.3 \%$ to $3.5 \%$ (2.3\% in 2011 and $2012,2.8 \%$ in $2013,3.1 \%$ in $2014,3.3 \%$ in 2015 and $2016,3.5 \%$ from

${ }^{44}$ Print No. 3946 of 10 March 201161 <http://ww2.senat.pl/k7/dok/sejm/073/3946.pdf $>$ accessed 8 October 2013. 
2017 and onward) by moving part of the retirement contribution to a newly created sub-account in the Social Security Institution;

- Funds held in the sub-account in the Social Security Institution will be indexed according to the average nominal GDP growth over the previous five years;

- Contributions in the sub-account in the Social Security Institution will be subject to division in the event of divorce or annulment of marriage, termination of community property during the marriage or contractual exclusion or limitation of statutory commonality between the insured and his/her spouse, and in the case of death of the insured. Assets attributable to the heirs will be paid in cash and recorded in their sub-accounts under the same principles as is currently the case in respect of OFEs;

- The investment limit in shares of companies listed on a regulated stock exchange has been raised to $90 \%$ of an open pension fund's assets. The target limit will be reached in 2034. In accordance with regulations, the limit was raised from $40 \%$ to $45 \%$ in 2012 . In 2013 and 2014 , the limit has risen to $47.5 \%$ and $50 \%$ respectively, and thereafter will increase annually 2 percentage points until reaching the target $(90 \%)$;

- In order to reduce the cost of operation of pension funds, on 1 January 2012 provisions entered into force prohibiting pension funds from engaging in sales activities and introducing a self-selection method on the basis of the insured receiving uniform, objective and timely information about open pension funds prepared and published by the Financial Supervision Authority (KNF);

- In respect of promoting supplemental insurance, the new law provides for the establishment of individual pension protection system accounts (IKZE) and assumes that IKZE deposits will be tax deductible. The value of payments to IKZEs was set at $4 \%$ of base pension contributions. 